ЛЮБЦОВА А. В.

ЦЕННОСТНЫЕ ОРИЕНТИРЫ СОВРЕМЕННОЙ МОЛОДЕЖИ В КОНТЕКСТЕ ФОРМИРОВАНИЯ ПРОСОЦИАЛЬНОГО ПОВЕДЕНИЯ РосСИЙСКИй пСИХологИЧЕСКИЙ ЖУРнАл, 2020, Т. 17, № 4, 65-79. doi: 10.21702/rpj.2020.4.5

СОЦИАЛЬНАЯ ПСИХОЛОГИЯ

УдК 159.99:316.62 doi: 10.21702/rpj.2020.4.5

Систематический обзор

\title{
Ценностные ориентиры современной молодежи В контексте формирования просоциального поведения
}

\author{
Алена В. Аюбцова \\ Балтийский фелеральный университет имени Иммануила Канта, г. Калининграл, Российская \\ Фелерация \\ E-mail: alena.lyubtsova@gmail.com \\ ORCID ID: https://orcid.org/0000-0003-4733-6807
}

\begin{abstract}
Аннотация
Введение. Целью статьи является исследование особенностей современных ценностных ориентиров молодежи и их влияния на просоциальное поведение Аанной возрастной категории. Рассмотрен олин из кАючевых проблемных аспектов социально-культурного познания - ценностная ориентация современных молоАых АюАей.

Теоретическое обоснование. Основная проблема заключается в отсутствии концептуальной и систематичной разработанности теоретических положений в отношении ценностных ориентиров и их взаимосвязи с ценностно-смысловой сорерой жизнеАеятельности молоАежи. Новизна исследования заключается в определении онтогенетических изменений в кажАом из компонентов конструкта психологии и социального развития современного поколения.

Результаты и их обсужАение. На основе аналитического обзора литературных источников выАелены основные ценностные ориентации молодежи и их тенАенции развития. В качестве гендерных особенностей проявления ценностей молоАого поколения выАеляется тот фракт, что основными социальными тренАами Аля субъектов женского пола по-прежнему остаются тралиционные ценности: семья, зАоровье, ^юбовь. ТогАа как преАставите^и мололежи мужского пола стремятся к самореализации. Основной мотивацией молодых АюАей к работе остается высокий уровень оп^аты труда, также молодые ^юАи заинтересованы в соответствии работы своим интересам. Обобщены и систематизированы результаты наработок современных исслеАОвателей в отношении возрастной специфрики связи просоциальности ^ичности с Аействием Аругих интрапсихических систем: волевой регуляцией, показателями интелмекта, социальной ответственностью. Отмечено влияние фракторов Аепривации мо^олежи (эгоистической мотивации и искажений в атрибутивной системе Аоверия к миру) на возрастной генезис просоциальности. Вылелено, что инициативность и интеллект Аетерминируют просоциальные тенАенции в периоА поАросткового, старшего Юношеского возраста и в периоА средней молоАости. Наш^а обоснование илея о целесообразности ориентироваться в программах стимулирования просоциальности на уровень зрелой просоциальности, которая предусматривает как вылеление объективных критериев целесообразности просоциальных фрорм поведения, так и развертывание рефлексивной субъектности, получение ^ичностного УАовольствия от Аействий на благо Аругого человека.
\end{abstract}


ЛЮБЦОвА А. В.

ЦЕННОСТНЫЕ ОРИЕНТИРЫ СОВРЕМЕННОЙ МОЛОДЕЖИ В КОНТЕКСТЕ ФОРМИРОВАНИЯ ПРОСОЦИАЛЬНОГО ПОВЕДЕНИЯ

Российский психологИчЕский жУРнАл, 2020, Т. 17, № 4, 65-79. doi: 10.21702/rpj.2020.4.5

СОЦИАЛЬНАЯ ПСИХОЛОГИЯ

\section{КАючевые слова}

молодежь, возрастные особенности, молодое поколение, просоциальное повеАение, социализация, мичность, ценностные ориентации, развитие, возрастной периол, полростковый возраст

\section{Основные положения}

> разработка проблемы генезиса просоциальности интенсифиццировалась в последние Аесятилетия;

\ психологический ракурс анализа особенностей ценностных ориентиров мололежи связан: с изучением ранних форм просоциального поведения; с прослеживанием возрастных закономерностей ее развития на кажАом этапе онтогенеза; с анализом особенностей процесса, возможностей его стимулирования;

> перспективы исслеАования особенностей современного молоАого поколения в рамках развития просоциального поведения обусловлены: открытием возможностей Аля прогнозирования процессов социального развития Аичности, прослеживанием его перспектив; обеспечением психолого-педагогического сопровожАения просоциального развития в соответствии с этапами развития френомена; упрощением и облегчением процесса анализа зрелых фрорм конструкта у мололежи.

\section{Для цитирования}

Любцова, А. В. (2020). Ценностные ориентиры современной молодежи в контексте формирования просоциального поведения. Российский психологический журнал, 17(4), 65-79. doi: 10.21702/rpj.2020.4.5

Дата получения рукописи: 10.08 .2020 Дата окончания рецензирования: 14.10 .2020 Дата принятия к публикации: 15.10 .2020

\section{Введение}

Характерная для современного общества трансформация социальных ценностей своеобразно сказывается на социальном опыте молодого поколения на субъективном личностном уровне. В последние десятилетия в России, по причине перманентных изменений внешней социально-экономической и политической среды, затрудняется выбор личностью социального вида поведения, ее надлежащее проявление, что обуславливает актуальность данного исследования. Целью статьи является определение характерных особенностей становления ценностной системы молодежи, которая влияет на просоциальное и антисоциальное поведение личности в современных условиях развития общества.

\section{Теоретическое обоснование}

Проблемы функционирования общества, особенности его влияния на жизнедеятельность и поведение молодого поколения и обратное влияние этих факторов на характер развития общества привлекали и привлекают внимание исследователей различных отраслей научного знания. Среди них в рамках данной статьи следует выделить таких, как: Н. В. Власова, Н. А. Драчук, И. С. Ефремов, Е. В. Ахмадеева, Н. В. Кухтова, П. А. Иванов, П. П. Кычкин, В. Я. Давыдова, К. О. Лазутко, С. А. Махин и др. 
ЛЮБЦОВА А. В.

ЦЕННОСТНЫЕ ОРИЕНТИРЫ СОВРЕМЕННОЙ МОЛОДЕЖИ В КОНТЕКСТЕ ФОРМИРОВАНИЯ ПРОСОЦИАЛЬНОГО ПОВЕДЕНИЯ РосСИЙСКИй пСИХологИЧЕСКИЙ ЖУРнАл, 2020, Т. 17, № 4, 65-79. doi: 10.21702/rpj.2020.4.5

СОЦИАЛЬНАЯ ПСИХОЛОГИЯ

Процессы трансформации общества, с позиции Жоховой (2016), обуславливают возникновение так называемого синдрома «современной личности», который охватывает следующие признаки: 1) открытость к инновациям и изменениям (что особенно важно в период информатизации общества и становления цифровой экономики, глобализационных процессов); 2) осознание количества существующих взглядов и мнений в окружающем социуме без национальных и стереотипных границ; 3) готовность выразить и обосновать свою позицию и в то же время терпимость по отношению к Другим; 4) способность концентрировать внимание больше на будущем, чем на прошлом; 5) ощущение субъективной силы; 6) стремление предвидеть тенденции в развитии событий и стратегически планировать свои действия; 7) доверие к социальному порядку; 8) целостное и адекватное осознание и принятие неизбежности имеющегося неравенства в распределении благ, аргументированных социальных привилегий; 9) стремление к самосовершенствованию, непрерывному образованию; 10) уважение достоинства других субъектов социума.

Ряд зарубежных авторов (напр., Bryant \& Crockenberg, 1980) отмечает, что от соблюдения или нарушения социального поведения, осуществления его на основе институционализации в обществе социальных норм или предпочтения их асоциальным типам зависит не только успешность социального становления отдельного индивида, его социального взаимодействия с другими людьми, но и эффективность развития всего общества. Поскольку поведение является чрезвычайно сложным по структуре, то оно, как и любая система, может быть рассмотрено в разных аспектах.

В наработках Л. С. Выготского подчеркивается, что молодость - это период процесса, в котором продуцируются и устанавливаются основные личностные характеристики субъекта, что институционализируется и контролируется историческими и культурными особенностями (Выготский, 2016). Согласно данным, указанным в исследованиях зарубежных авторов, хронологические границы молодежи зависят от социально-исторического развития страны (региона) проживания, культуры, методов и форм социализации, характерных для конкретного общества. В социологии нижний возрастной предел чаще всего определяется 14-16 годами, а верхний - 25-29 годами (Ribeiro da Silva, Rijo, \& Salekin, 2020).

К основным характеристикам этого жизненного периода авторы Власова (2018) и Дежевой (2018) относят материальную зависимость от членов семьи или системы социального обеспечения, а также аспекты влияния нестабильности социального и экономического положения. Ефремов и Ахмадеева (2018), Драчук (2018) подчеркивают основательную роль стремлений молодежи не принимать на себя обязательств по отношению к обществу, ближайшему окружению, самому себе, что расширяет границы возраста молодости.

Изыскания в рамках концепта молодости имеют смысл только в сравнении с другими возрастными группами, которые развиваются на основе незавершенности процесса первичной социализации личности, что влечет за собой определенную социальную незрелость молодых людей и тем самым ослабляет критерии оценки для нарушителей общественных норм и ценностей. Следующей концептуальной характеристикой дифференциации молодежи в социальной стратификации представляется их творческая активность и перспективность развития, которая находится в прямой зависимости от динамики формирования ценностных ориентаций (Lu, 2020; Scott \& Cnaan, 2020).

Следует подчеркнуть, что процесс формирования ценностной ориентации у молодежи еще далек от завершения, поэтому нет социального и психологического барьера для отказа 
ЛЮБЦОвА А. В.

ЦЕННОСТНЫЕ ОРИЕНТИРЫ СОВРЕМЕННОЙ МОЛОДЕЖИ В КОНТЕКСТЕ ФОРМИРОВАНИЯ ПРОСОЦИАЛЬНОГО ПОВЕДЕНИЯ

Российский психологИЧЕский жУРнАл, 2020, Т. 17, № 4, 65-79. doi: 10.21702/rpj.2020.4.5

СОЦИАЛЬНАЯ ПСИХОЛОГИЯ

от нового страха неудачи из-за отсутствия негативного опыта. Аргументирует указанную позицию утверждение Кычкина и Давыдовой (2018), которые отмечают, что для молодого поколения представляется характерным перманентное желание освоения неизвестных ранее инновационных объектов и субъектов действительности, а также отсутствие рефлексии в отношении вероятного риска последствий в будущем.

Перманентный рост динамики научно-технического прогресса приводит к повышению значения молодежи в социокультурном развитии общества и одновременному увеличению социокультурных различий между поколениями, что обусловлено ускоренным восстановлением условий жизнедеятельности, которое оказывает существенное влияние на структуру ценностных ориентаций молодежи, а вследствие этого - и всего общества (Rhodewalt \& Peterson, 2008).

Clarke (2016) отмечает, что в обыденном сознании личности процессы начального этапа социализации завершаются в том случае, когда молодой человек создал семью, т. е. берет на себя ответственность за продолжение рода, но в наше время этот критерий не является решающим, что позволяет говорить об изменении социально-психологических границ юного возраста. С одной стороны, нижняя граница подросткового возраста, которая традиционно ассоциируется с подростковым половым созреванием, значительно увеличилась. С другой стороны, процесс обучения, связанный с общественно необходимым временем подготовки к трудовой и социальной жизни, усиливается, а его незавершенность говорит об отсутствии социального статуса, что также поднимает верхнюю границу молодости как возрастного периода.

В настоящее время критериями социальной зрелости могут быть: завершение образовательного процесса и профессионального становления, переход к самостоятельной трудовой жизни, относительная независимость в финансовом плане от родителей (опекунов, иных родственников), вступление в брак и рождение первого ребенка, получение политических и гражданских прав. Эти критерии не могут действовать одновременно, но только их последовательность и комбинация дают человеку определенный социальный статус (Рубцов и др., 2018). Вступление в силу перечисленных выше составляющих концепта социальной зрелости у большинства членов социума молодого возраста происходит в промежутке от 14 до 35 лет.

\section{Результаты и их обсуждение}

Анализ фундаментальных положений в отношении особенностей молодежи как социально-демографической группы требует объективного отражения специфики объекта исследования, которая являет собой целостность комплексных социальных отношений, позволяющих идентифицировать специфику феномена. В возрасте от 14 до 35 лет человек приобретает устойчивый профессионально-трудовой статус в обществе (Wong, Khiatani, \& Chui, 2019). Ряд зарубежных авторов констатирует, что социальное самоопределение молодежи - это комплексная многоуровневая система личностного самоопределения, включающая: получение образования, сознательный выбор профессии, самоопределение в трудовой сфере, создание семьи, выбор места жительства, создание позиций в социально-политической и культурно-социальной сфере общества и т.д. (Gentzler, Palmer, Ford, Moran, \& Mauss, 2019).

В рамках концепции ценностей молодежи основой для сотен исследований за последние 20 лет была теория фундаментальных ценностей Ш. Шварца. Фундаментом концептуального 
ЛЮБЦОВА А. В.

ЦЕННОСТНЫЕ ОРИЕНТИРЫ СОВРЕМЕННОЙ МОЛОДЕЖИ В КОНТЕКСТЕ ФОРМИРОВАНИЯ ПРОСОЦИАЛЬНОГО ПОВЕДЕНИЯ РосСИЙСКИй пСИХологИЧЕСКИЙ ЖУРнАл, 2020, Т. 17, № 4, 65-79. doi: 10.21702/rpj.2020.4.5

СОЦИАЛЬНАЯ ПСИХОЛОГИЯ

подхода автора стала связь между 10-ю базовыми ценностями или 4-мя метаценностями с разными установками, мнениями, типами поведения, личностными чертами и социально-демографическими показателями. В исследованиях Ш. Шварца также измерялись характеристики развития ценностей в детском и подростковом возрасте и их изменения во времени. Центральный тезис теории, сформулированной Ш. Шварцом, отражал следующее: набор ценностей представляет собой мотивационный континуум, а мотивационные различия между ценностями можно считать скорее непрерывными, чем дискретными (Schwartz, Verkasalo, Antonovsky, \& Sagiv, 1997).

Процесс социального самоопределения молодежи характеризуется четкой поэтапностью. В соответствии с достижением социальных критериев зрелости молодых людей можно условно разделить на несколько групп, определяющих их положение в обществе и имеющих характерные особенности (Wong, Khiatani, \& Chui, 2019).

Подростковая группа (молодежь до 19 лет) состоит в основном из учеников общеобразовательных учебных заведений среднего звена, студентов средних профессиональных учебных заведений, студентов начальных курсов вузов. Материальная (в частности финансовая) зависимость от старшего поколения обосновывает относительно лояльное отношение к ценностным ориентирам и стандартам поведения окружающих, но незавершенность процессов формирования мировоззрения и информационная открытость, а точнее неопределенность личности в данных критериях, приводят к формированию ценностных ориентаций с взаимоисключающими ценностями. Следствием этого может быть отрицание любых социальных правил и норм, нигилизм (Магомедова, 2018).

Молодые люди в возрасте 20-25 лет, в основном, представляются группой студентов и субъектов, которые находятся в процессе завершения профессионального обучения. Следует отметить, что снижение общего уровня жизни населения в России привело к ранней занятости среди учащейся молодежи, необходимости работать, часто неквалифицированно, в свободное от учебы время. Данная группа является наиболее уязвимой, т. к. именно в этом возрастном периоде субъект находится в начале пути трудовой деятельности, но при этом не имеет высокого профессионального и социального опыта (Матвеева, 2018). Процесс усвоения социальных норм, традиций общества в этом возрасте уже проходит свою активную фазу, но формирование ценностных ориентаций продолжается в связи с активизацией практической деятельности молодых людей.

В 26-35 лет молодые люди в целом уже сделали профессиональный выбор, имеют определенную квалификацию и некоторый опыт труда, часто также к этому времени заводят семью. Данная возрастная группа субъектов часто в рамках ценностных ориентиров выдвигает высокие требования к трудовой сфере, что обусловливает наличие скрытой безработицы среди этой группы молодежи (долговременный выбор места работы). То есть, практическая деятельность индивида заставляет пересматривать сложившиеся ценностные ориентации. Если процесс бездействия, неопределенности социального статуса приобретает долговременный характер, то имеет место тенденция к просмотру индивидом социально-значимых ценностей, входящих в перечень ценностных ориентаций (Миронова, Семенова и Халеева, 2018).

Отечественные исследователи Хомутникова и Кирсанова (2018) обосновывают воздействие динамики политических, экономических и социальных изменений в конце XX-начале XXI в. на развитие постсоветской молодежи. В этот период в молодежной среде преобладают процессы дифференциации. В то же время интеграционные процессы менее заметны, чем процессы 
ЛЮБЦОвА А. В.

ЦЕННОСТНЫЕ ОРИЕНТИРЫ СОВРЕМЕННОЙ МОЛОДЕЖИ В КОНТЕКСТЕ ФОРМИРОВАНИЯ ПРОСОЦИАЛЬНОГО ПОВЕДЕНИЯ

Российский психологИЧЕский жУРнАл, 2020, Т. 17, № 4, 65-79. doi: 10.21702/rpj.2020.4.5

СОЦИАЛЬНАЯ ПСИХОЛОГИЯ

дифференциации. В основном это связано с тем, что постсоветские общества переживают глубокие социально-политические изменения, в связи с чем меняется социокультурная среда взаимодействия социальных групп в обществе (Фельдштейн, 1994). Следовательно, одной из ключевых проблем советской и постсоветской молодежи стала проблема имущественного неравенства. Возрастает концентрация внимания субъектов молодого возраста на материальном благополучии и статусе в обществе.

Молодые люди, унаследовавшие определенный социальный статус, усваивают разные, иногда совершенно противоположные, ценности в своих личностных убеждениях. Базирование на информационных данных в отношении социально-экономического положения молодого поколения, которые в официальном формате статистически продуцировать достаточно сложно, отражает объективную вариативность социальной статистики доходов и численности работников с частичной и удаленной занятостью, самозанятостью (Чернов, 2008). Молодые люди часто недостаточно понимают фактические доходы и расходы родительской семьи и поэтому не могут четко оценить свое благополучие (особенно характерно для молодежи школьного возраста).

Салядинова (2018) отмечает, что, не имея достаточного опыта и профессионального мастерства, молодые люди чаще других вынуждены выполнять самые непривлекательные виды работы, переживая неполноту социального статуса, обусловленную именно возрастом.

Как свидетельствуют результаты исследований Лазутко и Махина (2016), в ценностной ориентации существует определенная гендерная дифференциация мнений среди молодежи: если здоровье, семья и дети следуют в системе жизненных приоритетов субъектов женского пола (для многих очень важна любовь), то для мужчин на втором месте находятся материальное благополучие и профессиональная занятость, а для многих - экономическая независимость, что важнее, чем дети и семья. Это может быть связано с тем, что мужчины, как исторически сложилось, считаются «кормильцами», и выполнение функции члена семьи, обеспечивающего материальные блага, важно для самореализации молодых людей, и, следовательно, является предпосылкой для создания семьи и рождения детей.

Рассматривая аспекты социализации и адаптации молодого поколения в ценностном аспекте, следует выделить понятие «просоциальности», которая являет собой характеристику комплекса действий, свойственных для просоциального поведения (Иванов, 2015). Просоциальное поведение предполагает присущее личности сочувствие и чувство заботы о Других, а также поведение, помогающее или приносящее пользу другим людям. Иными словами, просоциальное поведение можно интерпретировать в качестве готовности помочь окружающим, которые в этом нуждаются - как материально, физически, так и морально, психологически (Bryant \& Crockenberg, 1980).

Основными факторами и характеристиками саморегуляции и регуляции поведения субъектов молодого поколения, как отмечается в наработках Сорокина (2019), являются ценностные ориентиры, ключевым образом отражающие ряд моральных норм и требований к молодежи. В данном контексте автором констатируется, что именно культура, не как социальный институт, а как характеристика развития субъекта, транслирует модели личности, стандарты, примеры хорошего поведения (в субъективном понимании).

Специфические черты и проявления поведения человека зависят прямым образом от характера выстроенных и образовавшихся под влиянием факторов извне взаимоотношений с другим субъектом или группой, к которой он принадлежит. Просоциальное (антисоциальное) 
ЛЮБЦОВА А. В.

ЦЕННОСТНЫЕ ОРИЕНТИРЫ СОВРЕМЕННОЙ МОЛОДЕЖИ В КОНТЕКСТЕ ФОРМИРОВАНИЯ ПРОСОЦИАЛЬНОГО ПОВЕДЕНИЯ РосСИЙСКИй пСИХологИЧЕСКИЙ ЖУРнАл, 2020, Т. 17, № 4, 65-79. doi: 10.21702/rpj.2020.4.5

СОЦИАЛЬНАЯ ПСИХОЛОГИЯ

поведение также находится под влиянием групповых норм и ценностей, положений о статусе и роли. Любцова и Серых (2019) констатируют в своих исследованиях, что действие молодого человека отличается поведением, состоящим из нескольких характерных личностных проявлений. Поведение каждого субъекта социума следует понимать в качестве системы взаимосвязанных действий по выполнению определенных функций, требующих связи между человеком и обществом. Социальное поведение - это относительно последовательный набор социально значимых действий человека. В наработках Молчановой (2013) поступок, как следствие действия и содержательный элемент поведения в целом, охарактеризован в качестве акта нравственного самоопределения индивида, в котором он утверждает себя как личность в своем отношении к другим людям, группам, обществу.

Проблема просоциальных поступков молодого человека представлена в психологической науке двумя линиями научных изысканий: о социальном поведении и в качестве анализа развития и функционирования ее диспозиционной основы - просоциальности. Отдельные аспекты просоциальности личности рассматриваются при решении смежных научных проблем: нравственного развития личности, изучении процессов социализации, возрастного генезиса альтруизма или эмпатии. Онтогенетический ракурс проблемы выделился в последние десятилетия (Свенцицкий и Казанцева, 2015).

Учитывая рассмотренные характеристики молодежи как возрастной категории, следует отметить, что показатели когнитивного развития человека в данном возрасте продолжают влиять на социальную самореализацию, не выполняя при этом определяющей роли. Социальная ответственность детерминирует социальную активность только при условии присутствия в ее иерархическом строении ориентации на благополучие партнеров. Просоциальность личности развивается в течение всей жизни. В целостный конструкт она выстраивается к концу подросткового возраста. С юношеского периода просоциальность личности функционирует на одном из четырех уровней: импульсивно-ситуативном, инертном, зрелой просоциальности или альтруизма (Кухтова, 2004).

По социальной значимости уровнем просоциальной самореализации является альтруизм. По критерию личностной значимости высшую меру производительности имеет зрелая просоциальность, которая обеспечивает для личности гармоничное сочетание двух типов ориентации: благо Другого и ченность Я как социального субъекта.

Значимым фактором возникновения индивидуального своеобразия в развитии просоциального поведения является процесс социализации (с первичными признаками индивидуализации), который особенно характерен для человека в молодом возрасте. Как свидетельствуют результаты исследований, специфика социального понимания и готовности к просоциальному поведению в большей степени связана с различиями в социализирующем воздействии родителей, чем с диспозиционной вариабельностью. Так, в ценностной сфере молодых людей еще в подростковый период происходят существенные перестройки. Признание ценности «доброта» снижается, в то время как «честность», «преданность» и «искренность» имеют восходящую динамику. Естественным источником изменений являются гормональные изменения.

Тенденцию к стабилизации просоциального поведения в научных исследованиях прослеживают как через призму анализа самооценки молодежи, так и посредством изучения мнений экспертов социологии и психологии. В работе зарубежных психологов эта закономерность выделяется на основе анализа мнений представителей двух основных институтов социализации - педагогов и родителей. Проанализировав мнения об изменении частоты просоциальных 
ЛЮБЦОвА А. В.

ЦЕННОСТНЫЕ ОРИЕНТИРЫ СОВРЕМЕННОЙ МОЛОДЕЖИ В КОНТЕКСТЕ ФОРМИРОВАНИЯ ПРОСОЦИАЛЬНОГО ПОВЕДЕНИЯ

Российский психологИЧЕский жУРнАл, 2020, Т. 17, № 4, 65-79. doi: 10.21702/rpj.2020.4.5

СОЦИАЛЬНАЯ ПСИХОЛОГИЯ

действий подростков по десяти критериям, авторы пришли к выводу о сохранении в течение года восходящей тенденции в развитии когнитивной составляющей просоциальности и стабилизации ее эмпатийных (эмпатия понимается как сознательное сопереживание текущему эмоциональному состоянию другого человека с учетом ощущения происхождения переживания) и поведенческих показателей. Достигая «плато», просоциальное поведение приобретает индивидуальную окраску и селективность (Салядинова, 2018).

Тенденцию к стабилизации просоциального развития чаще всего связывают именно со старшим подростковым возрастом или со всем периодом молодости. Ее основу образует смысловая система ценностного видения мира, ведущими механизмами которой являются рефлексия и смыслообразование.

Кроме процесса стабилизации в просоциальном развитии молодежи прослеживаются и другие закономерности. В исследованиях Clarke (2016) указывается на возникновение новых просоциальных тенденций - появление склонности к участию в волонтерских программах, повышение гражданской активности, развитие просоциальной идентичности, осознание личной ответственности за жизнь Других, ценностное отношение к ним.

В процессе обсуждения траектории развития просоциального поведения в старшем подростковом, юношеском периоде и молодости на основании аналитического обзора литературы выделяем несколько концептуальных оснований, позволяющих прогнозировать усиление просоциальных тенденций в течение этих периодов. Опираясь на исследования особенностей молодежи, становления их ценностных ориентиров в современном обществе, следует отметить, что благодаря развитию ценностной сферы в данном возрасте пассивное или делинквентное поведение воспринимается молодежью как проявление личностной незрелости. Большинство молодых людей считает, что важным критерием перехода к взрослой жизни является повышение внимания к окружающим, появление просоциальной ориентации и уменьшение самоориентации. В эти периоды продолжается интенсивное развитие социокогнитивных процессов, усвоение социальных точек зрения, что является важным условием развития просоциальных тенденций.

Анализируя позиции специалистов в отношении основных проявлений девиантного поведения молодежи, важно отметить, что в трансформационные периоды социально-экономических процессов российского общества повышается численность молодых людей, совершающих преступные деяния. Это позволяет предположить существование пропорционального соотношения проявлений девиантного поведения в виде преступности и отсутствия стабильности в обществе. Наибольшее число представителей категории молодежи, вовлеченных в преступную деятельность, было отражено статистикой в 1990-х и 2015-м гг.

По данным портала официальной правовой статистики Генеральной прокуратуры РФ, в 2015 г. количество совершенных преступлений в стране возросло на $9 \%$ по сравнению с 2014 г. (с 2190578 преступлений до 2388476 преступлений соответственно). При этом также возросла доля несовершеннолетних лиц, совершивших преступления в период 2014-2015 гг., на 3 \% (с 54369 до 55993 преступлений); положительная динамика доли учащихся и студентов, совершивших преступления, составила 2 \% (с 54870 до 55963 преступлений) (Показатели преступности России, н. д.).

Исходя из указанных данных, можно констатировать, что ключевыми причинами, объясняющими вовлечение молодежи в девиантные формы поведения, являются риск среды, к которой молодые люди адаптируются, а также переходный характер общества. 
ЛЮБЦОВА А. В.

ЦЕННОСТНЫЕ ОРИЕНТИРЫ СОВРЕМЕННОЙ МОЛОДЕЖИ В КОНТЕКСТЕ ФОРМИРОВАНИЯ ПРОСОЦИАЛЬНОГО ПОВЕДЕНИЯ РосСИЙСКИй пСИХологИЧЕСКИЙ ЖУРнАл, 2020, Т. 17, № 4, 65-79. doi: 10.21702/rpj.2020.4.5

СОЦИАЛЬНАЯ ПСИХОЛОГИЯ

В рамках анализа политического сознания современного молодого поколения следует выделить результаты исследования Поповой (2017). Итоги проведенного ею изучения политических ориентаций молодежи (возрастной категории от 14 до 30 лет) отражают, что ценности «сохранение традиций», «порядок» и «свобода» актуальны примерно для одного и того же количества опрашиваемых (примерно 45-46\%), в то время как «реализация реформ» представляется актуальной только для трети (34,9\%). В массовом сознании молодежи существует единое мнение о ценности «человеческие интересы». По крайней мере $72 \%$ респондентов считают их приоритетными по сравнению с интересами государства (18\%). Они полагают, что государству необходимо первично уделять внимание малообеспеченной молодежи, проживающей в небольших поселках (до 20000 жителей), а также студентам.

Сегодня сущностные характеристики деятельности молодых людей не сопровождаются их значительным вовлечением в общественно-политическую жизнь страны. Однако, как справедливо отмечают эксперты, это не должно соотноситься с реальной возможностью для определенных групп молодежи отстаивать свои интересы в случае необходимости (Поливаева и Беленикин, 2016). Кроме того, необходимо помнить, что в современном обществе массовое участие больше не является главным критерием уровня зрелости и развития гражданских инициатив, как в ранее рассмотренные периоды конца XX в.

В современных социально-экономических условиях молодые люди, которые родились уже после распада СССР и пережили последствия кризиса 1990-х гг., вступают в активную социальную жизнь. Можно предположить, что ориентированные на успех в построении карьеры, материальное благополучие молодые люди выберут кандидата, который, по их мнению, может гарантировать возможность полной реализации их жизненных планов. И наоборот, молодые люди, родители которых не смогли защитить себя от последствий социальных изменений, могут проявлять электоральную пассивность или полностью игнорировать политическую жизнь в стране. Не исключено, что они станут объектом манипуляций политического характера.

На современном этапе новые движения становятся движущей силой исторического развития. На смену традиционным организациям коллективного действия приходят современные акторы-новые социальные движения, группы, которые возникают при решении проблем посредством подходов прямого действия. Таким образом, возникает и внедряется модель современного гражданского участия, которая включает в себя добровольное движение. Это происходит из-за фрагментированной направленности группового и индивидуального участия, а также более широкого вовлечения граждан в процесс принятия решений на местном, национальном и глобальном уровнях.

В современном мире существуют альтернативные каналы влияния граждан молодого возраста на общественно-политический процесс, различные социальные сети. Характерной чертой новых социальных движений представляется качественная ориентация на современные, постматериалистические ценности и коллективную идентичность, которая основана не на классовых и социально-экономических различиях, а на формировании общей культурной идентичности, ценностно-нормативных рамок (Истомина и Оберемко, 2015).

Dekker \& Halman (2003), проводящие в своих исследованиях анализ взаимосвязи между социальным, политическим и протестным участием молодых людей в гражданских процессах, фокусируются на двух типах добровольного участия: социальном и политическом. Авторский анализ выявил наличие связи между типами участия, но она наименее очевидна между участием в общественной жизни и протестной активностью молодежи. 
ЛЮБЦОвА А. В.

ЦЕННОСТНЫЕ ОРИЕНТИРЫ СОВРЕМЕННОЙ МОЛОДЕЖИ В КОНТЕКСТЕ ФОРМИРОВАНИЯ ПРОСОЦИАЛЬНОГО ПОВЕДЕНИЯ

Российский психологИЧЕский жУРнАл, 2020, Т. 17, № 4, 65-79. doi: 10.21702/rpj.2020.4.5

СОЦИАЛЬНАЯ ПСИХОЛОГИЯ

Волонтерское движение - это ненасильственное объединение равноправных участников, которые в своей деятельности опираются на идеи волонтерства при реализации социальных инициатив, направленных на стимулирование/ограничение социальных изменений и решение социальных проблем. Волонтерское движение характеризуется следующими основными характеристиками: социально-экономический эффект; отсутствие или минимизация заработной платы; наличие социальных льгот; свободный выбор без принуждения и внешних обязательств; равенство волонтеров, работающих внутри организации и вне любых организованных форм деятельности (Уварова и Федосеева, 2015).

Молодежное волонтерское движение - это, с одной стороны, продукт, а с другой - элемент гражданского общества и его самоорганизации. Отсутствие единой научной концепции волонтерского движения выявляет трудности в разработке стратегии успешного развития гражданского общества.

Одновременно с повышением активности молодого поколения в направлениях попыток реформирования государства и добровольных акций помощи в виде волонтерства, гражданская позиция, активность молодых людей часто имеют негативные последствия, порожденные радикальностью взглядов на разные аспекты социокультурной жизни. Так, одной из самых актуальных проблем сегодня является проблема экстремизма среди молодежи, поскольку молодые люди в силу своих социально-психологических характеристик являются одними из наиболее уязвимых для идеологического влияния категорий населения. Поэтому идеологи экстремизма и терроризма считают молодое поколение главным источником вербовки своих последователей.

Радикально настроенные и нацеленные группы и организации проводят направленную идеологическую «обработку» молодежи, основанную по большей части на идеях религиозного или национального экстремизма. Идеологи террористических и религиозно-экстремистских организаций способствуют культивированию среди молодежи радикальных взглядов. В этом противостоянии с государством, с обществом используются все доступные средства. Об этих негативных тенденциях свидетельствует тот факт, что большинство людей на пути к экстремизму и вооруженному насилию - это молодые люди в возрасте от 16 до 30 лет (Васильев, Фисенко и Ужегова, 2016).

Причины, по которым молодые люди придерживаются радикальных экстремистских идей, могут быть политическими, социальными и экономическими. Главный резерв для различных радикальных организаций - это растущее число безработных молодых людей, которые в последнее время оказались в особо тяжелом положении. Когда научное сообщество и государство сталкиваются с проблемой взрослой жизни молодых людей, протесты становятся все более частыми, а настроения чрезвычайно агрессивными. Молодые люди являются неотъемлемой частью таких понятий, как любовь к риску, «чувство» экстремистской деятельности, способность самоутвердиться во взрослом мире плюс эмоциональная возбудимость, характерная для этого возраста, неспособность быстро привязываться и отсутствие навыков решения даже простых конфликтных ситуаций (Городенцев и Шеуджен, 2015).

Отсутствие социальной зрелости, профессионального и жизненного опыта и, как следствие, низкий социальный статус молодых людей в современном обществе делают экстремизм феноменом молодежи. По данным МВД РФ, сегодня в России действует около 150 молодежных экстремистских группировок. Растет не только количество, но и уровень преступности, насилие становится все более организованным, поскольку определенные политические 
ЛЮБЦОВА А. В.

ЦЕННОСТНЫЕ ОРИЕНТИРЫ СОВРЕМЕННОЙ МОЛОДЕЖИ В КОНТЕКСТЕ ФОРМИРОВАНИЯ ПРОСОЦИАЛЬНОГО ПОВЕДЕНИЯ РосСИЙСКИй пСИХологИЧЕСКИЙ ЖУРнАл, 2020, Т. 17, № 4, 65-79. doi: 10.21702/rpj.2020.4.5

СОЦИАЛЬНАЯ ПСИХОЛОГИЯ

и социальные структуры пытаются использовать молодых людей в своих целях, провоцируя их на экстремистские действия. Поэтому очевидно, что основной упор в борьбе с проявлениями экстремизма и терроризма среди молодежи должен быть сделан на их предотвращении и раннем предупреждении.

В разных странах, в том числе в России, профилактика экстремизма осуществляется законодательно закрепленными и мощными методами. Опыт последних лет показывает, что только наказательные методы борьбы с терроризмом не приносят ожидаемых результатов в отношении молодежи. Они необходимы, но не могут заменить психопрофилактические. Эти методы должны дополняться совместными действиями всех государственных органов при поддержке гражданского общества, науки, образования и деловых кругов. Особое место следует уделить семье, школе, университетам, религиозным лидерам, СМИ, деятелям литературы, кино, музыки, науки и т.д. Важно создать единое образовательное пространство «семья - школа - университет», где главную роль будет играть информационный ответ против экстремизма и терроризма в процессе обучения молодежи.

Развитие молодежного экстремизма указывает на недостаточность социальной адаптации молодых людей и развития их антиэкстремистского, антитеррористического мышления. Основными направлениями работы в сфере предотвращения экстремизма и терроризма в образовательном процессе будут: 1) практические рекомендации, необходимые для государства и общества; 2) научно обоснованный анализ исторических, культурных и философских аспектов процессов, происходящих в молодежной культуре; 3) разработка системы профилактических мероприятий, в том числе социально-культурных условий, по формированию толерантности у молодежи; 4) улучшение культурной и развлекательной деятельности молодого поколения; 5) создание авторитетных общественных молодежных организаций; 6) осознание необходимости самоопределения личности, воспитание культуры межнационального общения; 7) формирование духовно-нравственной атмосферы, взаимоуважения, основанного на принципах уважения прав и свобод человека, готовности к культурному взаимодействию; 8) анализ эффективности принимаемых мер по предупреждению проявлений экстремизма и ксенофобии у молодежи с необходимыми корректировками для повышения эффективности принимаемых мер.

Проведенное исследование позволяет сделать ряд следующих выводов:

1. Ценностные ориентиры в широком смысле - это выбор человеком определенных материальных и духовных ценностей, моральных и социальных установок, определяющих его образ жизни, формирующих отношение к окружающему миру.

2. В период первичной социализации индивида формируются его сознание, самосознание, нормы поведения, моральные качества, мировоззрение. Молодежь как особая часть общества постоянно находится в фокусе социологических исследований: в молодежной среде обычно отсутствует устойчивая система и иерархия ценностей - ценности легко поддаются влияниям и быстро меняются. Иерархия ценностей молодежи может отличаться от иерархии ценностей населения в целом.

3. В историческом ракурсе динамика ценностей молодежи прямо или косвенно зависит от трансформаций традиционных ценностей поколений и общественно-экономических факторов развития.

4. На фоне ценностей, жизненных ориентиров и ожиданий молодежи происходит ее развитие, стремление к благосостоянию и счастью, ценности определяют контекст и направление развития, восприятие благополучия. 
ЛЮБЦОвА А. В.

ЦЕННОСТНЫЕ ОРИЕНТИРЫ СОВРЕМЕННОЙ МОЛОДЕЖИ В КОНТЕКСТЕ ФОРМИРОВАНИЯ ПРОСОЦИАЛЬНОГО ПОВЕДЕНИЯ

Российский психологИЧЕский жУРнАл, 2020, Т. 17, № 4, 65-79. doi: 10.21702/rpj.2020.4.5

СОЦИАЛЬНАЯ ПСИХОЛОГИЯ

5. Совокупность личностно значимых стремлений личности представляет собой направленность устойчивых мотивов, лежащих в основе ориентации субъекта в социальной среде и его оценок ситуаций. Они могут иметь разную степень осознания, причем, будучи направленными на значимые для личности цели, автоматически не будут продуцировать активные действия человека по их достижению в реальной действительности. Особенно это касается лиц молодого возраста, обладающих довольно сильными стремлениями, которые, однако, часто не подкреплены высокой способностью к их реализации в силу недостаточного багажа знаний, несостоявшихся в полной мере умений, переоценки собственных возможностей и идеализации обстоятельств реальной действительности. Приоритет внутренних ценностей над внешними позволяет утверждать, что у молодежи преобладает саморазвивающаяся система ценностей над самопрезентативной, когда молодые люди скорее предпочитают мотив «быть», чем мотив «казаться».

6. На современном этапе ценностные ориентиры молодежи имеют определенные особенности в зависимости от индивидуально-психологических и социально-экономических условий формирования и развития личности. Формирование гражданской позиции и социальной активности происходит у молодых людей, которым в качестве индивидуальных характеристик присущи гуманизм, бережное отношение к окружающей среде, уважение к национальным традициям. Кроме того, такие молодые люди становятся толерантнее по отношению к другим нациям, преданными национальным и государственным интересам.

7. Современная молодежь стремится приобретать те или иные культурные блага и услуги, а именно: получать образование, посещать культурные центры, заниматься саморазвитием и т. д.

8. В эпоху процессов глобализации и развития информационного общества возникает проблема негативного влияния информационных потоков разного характера на молодых людей, у которых еще не сформирована гражданская позиция, идеология. Недостаток знаний в разных сферах (политике, религии и пр.) у молодежи приводит к ситуации легкого оказания внешнего влияния на их мировоззрение и мировосприятие, что требует особого внимания в части их воспитания и образования, соответствующего просвещения.

\section{Заключение}

Таким образом, следует констатировать, что в современном обществе наблюдается тенденция удлинения формальных сроков завершения процесса первичной социализации молодых людей, что влияет на формирование ценностных ориентиров молодежи. Духовные ценности в ценностных ориентирах молодежи уступают свое место материальным, экономическим ценностям, что актуализирует поиск решений вопроса просоциального поведения среди молодых людей.

В целом у молодежи наблюдается прогресс в развитии различных аспектов функционирования просоциальности. К концу юношеского периода этот процесс замедляется, а затем снова повышается после 25-26 лет. Отметим, что несмотря на попытки распространять выводы на развитие всего просоциального конструкта, их целесообразно относить, прежде всего, к когнитивным основам стратегии социокультурного развития и самооценочным суждениям.

В вопросах просоциального развития личности молодых людей прослеживаются две взаимосвязанные линии: анализ просоциального поведения и изучение просоциальности личности как ее диспозиционного основания. В первом случае внимание сосредоточивается 
ЛЮБЦОВА А. В.

ЦЕННОСТНЫЕ ОРИЕНТИРЫ СОВРЕМЕННОЙ МОЛОДЕЖИ В КОНТЕКСТЕ ФОРМИРОВАНИЯ ПРОСОЦИАЛЬНОГО ПОВЕДЕНИЯ

РосСИЙСКИй пСИХологИЧЕСКИЙ ЖУРнАл, 2020, Т. 17, № 4, 65-79. doi: 10.21702/rpj.2020.4.5

СОЦИАЛЬНАЯ ПСИХОЛОГИЯ

на детерминации, особенностях, формах, видах просоциальной активности. Во втором - предметом анализа является уникальный конструкт психики, который обусловливает готовность личности действовать на благо Другого.

\section{Литература}

Васильев, Н. Г., Фисенко, А. А. и Ужегова, А. В. (2016). Социологический анализ восприятия экстремизма и терроризма в молодежной среде. В Актуальные проблемы противодействия экстремизму и терроризму в молодёжной среде (с. 18-21). Ижевск: Информационноиздательский отдел «Бон Анца».

Власова, Н.В. (2018). Психологические особенности профилактики аддиктивного поведения современной молодежи. Мир образования - образование в мире, 1, 178-185.

Выготский, Л. С. (2016). Психология развития. Избранные работы. Москва: Юрайт.

Городенцев, Г. А. и Шеуджен, Н. А. (2015). Молодежный экстремизм в условиях современного российского общества: факторы генезиса и особенности проявления. Общество и право, 3, 22-25.

Дежевой, А. В. (2018). Особенности мировоззрения молодежи XXI века. Научный аспект, $1-1,141-143$.

Драчук, Н. А. (2018). Особенности социального самочувствия молодежи крупного города. Экономика и общество, 1, 111-120.

Ефремов, И. С. и Ахмадеева, Е. В. (2018). Особенности психологической взаимосвязи смысложизненных ориентаций и субъективного ощущения счастья у студенческой молодежи. Территория инноваций, 1, 61-67.

Жохова, Н. Н. (2016). Аспекты преобразования психики человека в пространстве электронной культуры. Современная наука: Актуальные проблемы теории и практики. Серия Познание, 7-8, 37-43.

Иванов, П. А. (2015). Установка на просоциальное поведение как содержание нравственного воспитания. Социология, 1, 176-182.

Истомина, А. Г. и Оберемко, О. А. (2015). Легитимация протестного участия волонтеров. Мониторинг общественного мнения: Экономические и социальные перемены, 6, 32-47. doi: $10.14515 /$ monitoring.2015.6.03

Кухтова, Н. В. (2004). Феномен просоциального поведения в психологической науке (некоторые подходы в изучении просоциального поведения). Белорусский психологический журнал, 1, 60-65.

Кычкин, П. П. и Давыдова, В. Я. (2018). Личностные особенности студенческой молодежи, увлеченной неформальной культурой. Казанский социально-гуманитарный вестник, 3, 45-48. doi: 10.24153/2079-5912-2018-9-3-45-48

Лазутко, К. О. и Махин, С. А. (2016). Половозрастные особенности взаимосвязи между личностной эмпатией, альтруизмом и эгоизмом. Ученые записки Крымского федерального университета имени В. И. Вернадского. Социология. Педагогика. Психология, 2(4), 105-113.

Любцова, А. В. и Серых, А. Б. (2019). Личностные детерминанты просоциального и асоциального поведения молодежи. Санкт-Петербургский университетский консорциум, 9, 71-75.

Магомедова, Н. Г. (2018). Этнопедагогические особенности межкультурной коммуникации молодежи. Известия Волгоградского государственного педагогического университета, $6,58-62$. 
ЛЮБЦОвА А. В.

ЦЕННОСТНЫЕ ОРИЕНТИРЫ СОВРЕМЕННОЙ МОЛОДЕЖИ В КОНТЕКСТЕ ФОРМИРОВАНИЯ ПРОСОЦИАЛЬНОГО ПОВЕДЕНИЯ

Российский психологИЧЕский жУРнАл, 2020, Т. 17, № 4, 65-79. doi: 10.21702/rpj.2020.4.5

СОЦИАЛЬНАЯ ПСИХОЛОГИЯ

Матвеева, Н. С. (2018). Особенности конфликтогенности современной студенческой молодежи. Устойчивое развитие науки и образования, 7, 197-201.

Миронова, В. А., Семенова, Е. А. и Халеева, А. С. (2018). Девиантное поведение молодежи вследствие употребления психоактивных веществ и особенности развития сексуального профиля. Центральный научный вестник, 3(11), 18-22.

Молчанова, Н. В. (2013). Просоциальное поведение как условие эффективного межкультурного взаимодействия. Известия Саратовского университета. Новая серия. Серия: Акмеология образования. Психология развития, 2(1), 3-7.

Показатели преступности России (н. д.). Генеральная прокуратура Российской Федерации: портал правовой статистики. Доступ 16 августа 2020, источник http://crimestat.ru/ offenses chart

Поливаева, Н. П. и Беленикин, Р.О.(2016). Особенности российской молодежи как субъекта гражданского общества. Власть, 24(3), 83-87.

Попова, О. В. (2017). Особенности политического сознания современной российской молодежи. Политическая наука, 1, 138-162.

Рубцов, В. В., Коул, М., Верч, Дж., Асмолов, А. Г., Эльконин, Б. Д., Лекторский, В. А., ... Гуружапов, В. А. (2018). Творческий потенциал культуры и человеческое развитие (круглый стол методологического семинара под руководством В. В. Рубцова и Б. Д. Эльконина). Культурно-историческая психология, 14(4), 41-51. doi: 10.17759/chp.2018140406

Салядинова, Э. Э. (2018). Психологические особенности ценностных ориентации молодежи в условиях социальной депривации. Форум молодых ученых, 5-3, 110-116.

Свенцицкий, А. Л. и Казанцева, Т. В. (2015). Повседневное просоциальное поведение личности как накопление социального капитала. Вестник Санкт-Петербургского университета. Серия 12. Психология. Социология. Педагогика, 2, 45-55.

Сорокин, О. В. (2019). Особенности девиантного поведения российской молодежи в условиях изменяющейся социальной реальности. Научный результат. Социология и управление, 5(4), 80-90. doi: 10.18413/2408-9338-2019-5-4-0-7

Уварова, В. И. и Федосеева, М. А. (2015). Волонтерская деятельность как форма самоорганизации молодежи: проблемы и подходы. Ученые записки Орловского государственного университета. Серия: Гуманитарные и социальные науки, 1, 91-96.

Фельдштейн, Д. И. (1994). Личностное развитие растущих людей в условиях социально-экономического кризиса. Москва: Наука.

Хомутникова, Е. А. и Кирсанова, А. Ю. (2018). Особенности самооценки студенческой молодежи. Аллея науки, 3(3), 617-619.

Чернов, А. Ю. (2008). Качественный подход в психологическом исследовании: монография. Волгоград: Изд-во ВолГУ.

Bryant, B. K., \& Crockenberg, S. B. (1980). Correlates and dimensions of prosocial behavior: A study of female siblings with their mothers. Child Development, 51(2), 529-544. doi: 10.2307/1129288

Clarke, D. (2003). Pro-social and anti-social behaviour. London; New York: Routledge.

Dekker, P., \& Halman, L. (Eds.). (2003). The values of volunteering: Cross-cultural perspectives. New York: Springer Science + Business Media.

Gentzler, A. L., Palmer, C. A., Ford, B. Q., Moran, K. M., \& Mauss, I. B. (2019). Valuing happiness in youth: Associations with depressive symptoms and well-being. Journal of Applied Developmental Psychology, 62, 220-230. doi: 10.1016/j.appdev.2019.03.001 
ЛЮБЦОвА А. В.

ЦЕННОСТНЫЕ ОРИЕНТИРЫ СОВРЕМЕННОЙ МОЛОДЕЖИ В КОНТЕКСТЕ ФОРМИРОВАНИЯ ПРОСОЦИАЛЬНОГО ПОВЕДЕНИЯ

РОССИЙСКИЙ ПСИХОЛОГИЧЕСКИЙ ЖУРНАл, 2020, Т. 17, № 4, 65-79. doi: 10.21702/rpj.2020.4.5

Lu, Sh. (2020). Family migration and youth psychosocial development: An ecological perspective. Children and Youth Services Review, 113, 911-953. doi: 10.1016/j.childyouth.2020.104953

Rhodewalt, F., \& Peterson, B. (2008). The Self and social behavior: The fragile Self and interpersonal self-regulation. In F. Rhodewalt (Ed.), Personality and Social Behavior (pp. 49-78). New York: Psychology Press.

Ribeiro da Silva, D., Rijo, D., \& Salekin, R. T. (2020). Psychopathic traits in children and youth: The state-of-the-art after 30 years of research. Aggression and Violent Behavior. doi: 10.1016/j. avb.2020.101454

Schwartz, Sh. H., Verkasalo, M., Antonovsky, A., \& Sagiv, L. (1997). Value priorities and social desirability: Much substance, some style. British Journal of Social Psychology, 36(1), 3-18. doi: 10.1111/j.2044-8309.1997.tb01115.x

Scott, M. L., \& Cnaan, R. A. (2020). Youth and religion in an age of global citizenship identification: An 18-country study of youth. Children and Youth Services Review, 110. doi: 10.1016/j. childyouth.2020.104754

Wong, M., Y. H., Khiatani, P. V., \& Chui, W. H. (2019). Understanding youth activism and radicalism: Chinese values and socialization. The Social Science Journal, 56(2), 255-267. doi: 10.1016/j. soscij.2018.08.006

\section{Конфликт интересов отсутствует}

